\title{
Alkaline Ceramidase 1
}

National Cancer Institute

\section{Source}

National Cancer Institute. Alkaline Ceramidase 1. NCI Thesaurus. Code C103892.

Alkaline ceramidase 1 (264 aa, $\sim 31 \mathrm{kDa}$ ) is encoded by the human ACER1 gene. This protein is involved in the catabolism of sphingolipid ceramides. 